\title{
SUPERVISI AKADEMIK KEPALA SEKOLAH DALAM MENINGKATKAN KINERJA GURU KEJURUAN
}

\author{
Tjipto Djuhartono ${ }^{1}$ Ulfiah $^{2}$, Hanafiah $^{3}$, Deti Rostini ${ }^{4}$ \\ Universitas Indraprasta PGRI, Jakarta, Indonesia ${ }^{1}$ \\ Universitas Islam Negeri Sunan Gunung Jati, Bandung, Indonesia ${ }^{2}$ \\ Universitas Islam Nusantara, Bandung, Indonesia ${ }^{34}$ \\ tjiptodjuhartono@gmail.com¹, ulfiah@fkipuinsgd.ac.id ${ }^{2}$, hanafiah@fkip-uninus.ac.id ${ }^{3}$, \\ deti.rostini@uninus.ac.id ${ }^{4}$
}

$\begin{array}{ll}\text { Received: } & 25 \text { Februari } 2021 \\ \text { Revised: } & \text { 09 Maret } 2021 \\ \text { Accepted: } & \text { 11 Maret } 2021\end{array}$

\begin{abstract}
This study aims to determine the academic supervision of Principals in Vocational High Schools in improving the performance of vocational teachers, specifically this study wants to find out the problems and efforts of the academic division in improving teacher performance in terms of planning, organizing, implementing, evaluating, following up, and problems and solutions. The method used in this research is a qualitative approach with a case study method of data collection and analysis techniques, namely interviews, observation and documentation study with trianguals. As a source of research data refers to the principal, teachers, students, education staff, people parents and supervisor of the Vocational High School of Bekasi city. The results of the study are a mapping of the performance of vocational teachers from the implementation of the school principal's academic supervision program, which has a clear direction towards positive change for all vocational teacher activities in learning that have a simultaneous impact on teacher performance and improvement of the quality of vocational high school education in Bekasi city. Thus the researcher recommends that the principal as a leader in the school can continue to develop teacher competencies given the rapid changes in science and technology followed by the labor market in the business and industrial world. And the output is the concept of the principal's academic supervision model for vocational teachers.
\end{abstract}

Keywords: Academic Supervision; Principal; Vocational Teacher; Performance

(*) Corresponding Author:

Djuhartono, tjiptodjuhartono@gmail.com,+62 8129967504

How to Cite: Djuhartono, T., Ulfiah, Hanafiah, \& Rostini, D. (2021). Supervisi Akademik Kepala Sekolah Dalam Meningkatkan Kinerja Guru Kejuruan. Research and Development Journal of Education, 7 (1), 101115.

\section{INTRODUCTION}

Sekolah sebagai intstitusi formal pendidikan akan menjadi dikenal dan baik mutunya tentunya tidak lepas dari unsur-unsur komponen yang ada di sekolah seperti guru, peserta didik, pengelola sekolah, dan fasilitas sekolah itu sendiri. Dan harapannya tentu harus sesuai dengan tujuan pendidikan nasional. Dalam penelitiannya, Mulyasa (2020:674) menyatakan "Pilar utama dalam merekonstruksi sumber daya manusia di Indonesia dilakukan melalui proses pendidikan yang sesuai dengan Standar Pendidikan Nasional (SPN)". Jadi semakin jelas kemajuan suatu bangsa dapat terlihat dari luaran pendidikan yang ada.

Sejalan dengan hal di atas guru dalam menjalankan tugasnya, tentunya harus sesuai dengan kompetensi yang dimilikinya sebagai dasar mengajar bidang studi yang ada di sekolah. Tetapi saat ini yang terjadi proses penugasan guru terkadang tidak sesuai dengan 
latar belakang pendidikan guru, yang mengakibatkan terjadi ketidakberdayaan guru mengajar. Dan yang fatal adalah peserta didik merasakan tidak mendapatkan ilmu yangseharusnya diterima. Guru mengajar hanya sekedar mengugurkan kewajiban tugas atau ingin mendapatkan income yang lebih. Kondisi di atas terlihat dengan data statistik yang menyatakan guru SMK khusunya Jawa Barat menunjukan kekurangan guru sebesar 29,504 orang dan khusunya guru Kejuruan sebesar 2,324 orang (Kintamani, 2016:46-47).

Dalam "Analisis Sumber Daya Manusia Pendidikan Dasar dan Menengah Tahun 2015/2016" dinyatakan "Kondisi kinerja guru secara nasional salah satu diantaranya menunjukan kinerja guru Jawa Barat menunjukan pada peringkat terbawah dari seluruh provinsi yang ada di Indonesia yaitu nilai sebesar 71,42 yang artinya katagori kurang" (Kintamani, 2016:91). Ditambah lagi Yunus (dalam detik.com, 2017) menyatakan kualitas pendidikan di Indonesia masih jauh dari memadai. Besarnya anggaran pendidikan pun tidak serta merta menjadikan kualitas pendidikan meningkat. Mengapa? Karena kualitas guru masih bermasalah. Suka tidak suka, hasil Uji Kompetensi Guru (UKG) tahun 2015, rata-rata nasional hanya 44,5 jauh di bawah nilai standar 75. Bahkan kompetensi pedagodik, yang menjadi kompetensi utama guru pun belum menggembirakan. Masih banyak guru yang cara mengajarnya kurang baik, cara mengajar di kelas membosankan. Inilah momentum yang tepat untuk mengkritisi soal kompetensi guru.

Setiap guru yang mempunyai kinerja baik tentunya diawali dengan kemampuan kompetensi yang dimiliki guru serta menjalankan tugas yang di terimanya dari sekolah. Kualifikasi guru seperti yang dinyatakan dalam Standar Pendidikan Nasional (SNP) Pasal 28 bahwa "Pendidik harus memiliki kualifikasi akademik dan kompetensi sebagai agen pembelajaran, sehat jasmani dan rohani, serta memiliki kemampuan untuk mewujudkan tujuan Pendidikan Nasional" (Mulyasa, 2013:53). Proses pembelajaran yang terjadi di sekolah banyak dikendalikan oleh guru dengan pantauan kepala sekolah, sehingga peran penting guru mengembangkan standar proses dalam kurikulum di Sekolah Menegah Kejuruan sangat dibutuhkan. Kreatifitas guru kejuruan yang terjadi di sekolah Menengah Kejuruan dituntut lebih banyak praktek dari teori tentunya. Tetapi yang terjadi di pelaksanaan ternyata lebih banyak teori dari prakteknya. Seharusanya matapelajaran kompetensi keahlian yang harus di uji praktek banyak tidak dilakukan sehingga kerugian ada pada siswa.

Harapan lain dalam fenomena disekolah adalah berkaitan dengan supervisi kepala sekolah, dimana sosok kepala sekolah dapat melakukan pendekatan sebagai pembimbing kepada seluruh guru dan staf yang ada di sekolah. Selain itu proses dalam menjalankan roda pendidikan disekolah, seorang kepala sekolah juga menjalankan supervisi akademik yang harapannya adalah adanya peningkatan dari kinerja guru. Hasil penelitian implementasi supervisi akademik dilakukan melalui 3 (tiga) tahap, yaitu perencanaan, pelaksanaan, dan evaluasi atau tindak lanjut dari supervisi tersebut (Leniwati 2017:113). Dalam perencanaan, kepala sekolah menerbitkan surat keputusan (SK) yang dilampiri jadwal pelaksanaan supervisi. Dalam pelaksanaannya, kegiatan supervisi dilaksanakan dengan cara biasa (di luar kelas) dan klinis ( dalam kelas). Guru - guru merespon positif supervisi akademik oleh kepala sekolah karena kegiatan supervisi sangatlah penting dilakukan untuk mengubah kinerja guru menjadi lebih baik.

Hasil dari supervisi akademik ini tentunya juga berimbas kinerja guru yang juga pada mutu pembelajaran di sekolah. Sesuai dengan penelitian bahwa pelaksanaan program supervisi akademik harus lebih mengarah kepada subjek guru sebagai fasilitator pembelajaran di kelas (Syukri 2015:83-84). Dari tinjauan tersebut dapat dipahami bahwa program kerja supervisi akademik hendaknya memberi pertolongan kepada guru dalam penyampaian pembelajaran. Begitu juga Susanto menyatakan dalam penelitiannya dalam bahwa "Dalam mewujudkan kinerja guru kejuruan yang sesuai dengan harapan 
dibutuhkan seorang kepala sekolah profesional. Kepala Sekolah sebagai bagian dari sistem sekolah menduduki posisi strategis dalam mengarahkan dan mendukung aktivitas guru dalam pembelajaran siswa" (Susanto: 2012;199). Selanjutnya dalam kemampuan supervisi, kemampuan kepala sekolah yang tertinggi dalam merencanakan program supervisi akademik dalam rangka peningkatan profesionalisme guru, dan kemampuan terendah dalam menindaklanjuti hasil supervisi akademik dalam rangka peningkatan profesionalisme guru (Rostini ,16:13-14).

Dalam rangka mempertahankan dan meningkatkan kinerja guru yang berdampak pada keberhasilan peserta didik yang belajar di SMK secara rutin setiap tahun menjalankan supervisi yang dipersiapkan setiap awal tahun pelajaran pada agenda lokakarya guru dan tenaga kependidikan serta mengundang pengawas dan nara sumber yang berkompeten. Dalam proses supervisi kepala sekolah mempunyai tim supervisor yang teridiri dari guru senior, kepala kompetensi, dan ada juga yayasan.

\section{LITERATURE REVIEW}

Penelitian ini menggunakan landasan teori mengenai supervisi, menurut Sergiovani dan Starrat supervisi merupakan suatu proses yang dirancang secara khusus untuk membantu para guru dan supervisor dalam mempelajari tugas sehari- hari di sekolah; agar dapat menggunakan pengetahuan dan kemampuannya untuk memberikan layanan yang lebih baik pada orang tua peserta didik dan sekolah, serta berupaya menjadikan sekolah sebagai masyarakat belajar yang lebih efektif (Mulyasa, 2017:252). Selanjutnya, Purwanto (2014:77) mengemukakan "Segala bantuan dari para pemimpin sekolah, yang tertuju kepada perkembangan kepemimpinan guru-guru dan personel sekolah lainya di dalam mencapai tujuan tujuan pendidikan". Jadi, supervisi bukanlah semata pengawasan tetapi lebih bermakna pada proses pendampingan kepala sekolah yang berfungsi sebagai supervisor dalam menidentifikasi guru gurunya dalam mempersipakan pengajaran, pelaksanaan pengajaran, membantu dan memberikan jalan keluar bagi guru yang mengalami kesulitan sampai dengan proses evaluasi dalam tugas guru tersebut dan mencipatakan masayarakat belajar yang memberikan kepuasan bagi orang tua siswa dan sekolah itu sendiri. Semakin jelas pada pokoknya supervisi merupakan proses yang mempunyai tahapan dalam melaksanakannya sehingga guru mersakan adanya perubahan yang lebih baik dalam mencapai tujuan pembelajaran.

Memperkuat teori di atas, Glickman menyatakan secara spesifik bahwa Supervisi Akademik adalah serangkaian kegiatan untuk membantu guru mengembangkan kemampuannya mengelola proses pembelajaran demi pencapaian tujuan pembelajaran. Semakin jelas pada pokoknya supervisi merupakan proses yang mempunyai tahapan dalam melaksanakannya sehingga guru mersakan adanya perubahan yang lebih baik dalam mencapai tujuan pembelajaran (Suharsaputra, 2018:164). Pengelolaan supervisi yang dijalankan merujuk pada langkah langkah fungsi fungsi manajemen ini menjadi bagian yang penting dalam penelitian ini, adapun fungsi fungsi manajemen yang paling umum dikemukakan oleh G.R Terry yaitu planning, organizing, actuating, controlling” (Fiyanto, 2014:10). Sehingga supervise akan mengetahui arah , panduan dan tujuan yang dicapai. Adapun secara operasional langkah langkah yang perlu dijalani diantaranya:

a. Perencanaan Supervisi Akademik

Perencanaan supervisi akademik di sekolah sangat penting sebagai acuan supervisor menjalankan tugasnya, adanya rambu rambu yang mendampinginya sehingga tidak bias. Perencanaan program supervisi akademik dibuat untuk sepanjang tahun pelajaran sejak awal tahun sampai akhir tahun pelajaran. 


\section{b. Pengorganisasian Supervisi Akademik}

Perorganisasian dalam supervisi akademik tentunya berkisar sebuah lembaga yang berjalan dengan personal yang ada di dalam dan dan tiap personal mempunyai pembagian tugasnya masing masing.

c. Pelaksanaan Supervisi Akademik

Tahap berikut dalam menjalani program supervisi akademik adalah proses pelaksanaan yang dilakukan oleh kepala sekolah beserta tim supervisor. Kepala sekolah dalam melaksanakan supervisi dapat mengunakan pendekatan dan teknik supervisi yang tepat (Suharsaputra: 2018:122). Beragam teknik supervisi dapat dipakai oleh kepala sekolah uuntuk mendampingi guru dalam menjalani tugas guru yang berdampak pada peningkatan kerja guru. Proses pendekatan teknik supervisi dapat menggunakan bersifat Induvidu dan kelompok diantaranya: Kunjungan dan Observasi kelas, Percakapan Pribadi, Diskusi Kelompok, Demonstrasi mengajar, Perpustakaan Profesional.

d. Evaluasi Supervisi Akademik

Evaluasi merupakan tahapan dalam rangka mengambil penilaian yang berdasarkan kegiatan yang dilakukan mulai dari perencanaan sampai dengan pelaskanaan, sehingga terpetakan kondisi tebaru dari hasil supervsisi akademik yang kemudian akan dapat digunakan utnuk tindak lanjut. Evaluasi supervisi akademik ini meliputi : a) Keterbacaan dan keterlaksanaan program supervise; b) Keterbacaan dan kemantapan instrument; c) Hasil supervisi; d) Kendala yang dihadapi dan upaya pemecahannya (Maunah: 2017,276).

e. Masalah dalam Supervisi Akademik

Dalam proses supervisi di sekolah tidak selalu lancar dan mendapatkan hasil yang makasimal. Sering terjadi dilapangan tidak sinkronnya antara supervisor dengan guru yang di supervisi seperti hasil belajar siswa yang tidak memuaskan, masih banyak guru yang malas dan lain sebagainya. Atau kreatifitas mengajar yang rendah.

Berberapa kendala yang muncul saat supervisi diantaranya: a) Kurangnya ghirah keilmuan guru; b) Pemimpin yang kurang berwibawa; c) Lemahnya kreativitas; d) Mengedepankan formalitas, mengabaikan esensi; e) Kuragnya fasilitas (Asmani: 2012,67-178). Dari kendala menunjukan kurang kemampuan guru dibidang keilmuannya dan kurnag tertarik untuk terus belajar, menyebakan potensi tidak muncul dan akhirnya proses belajar menjadi monoton. Dampak selanjutnya kepemimpinan yang lemah, tidak konsekwen dalam supervisi dan kesibukan kepemimpinan menyebabkan fungsi supervisor tidak berjalan semestinya.

Proses pelaksanaan belajar mengajar merupakan salah satu kinerja guru untuk menghasilkan siswa yang bermutu. Dengan demikian kinerja tentunya mempuayai arah dan capaian). Kinerja meruapakan gambaran tingkat pencapaian pelaksanaan suatu tujuan kegiatan atau program dalam mewujudkan sasaran, tujuan, visi, misi organisasi (Mulyadi: 2018:175). Untuk mengetahui kinerja guru berjalan sesuai dengan rencana dan mencapai target tentunya diperlukan proses pengawasan yang dilakukan oleh kepala sekolah selaku supervisor. Tugas dalam melaksanakan supervisi meliputi kegiatan yang memberikan bimbingan, bantuan, pengawasan dan penilaian pada msalah masalah yang berhubungan dengan teknis penyelenggaraan dan peningkatan pendidikan dan pengajaran untuk menciptakan situasi belajar mengajar yang lebih baik (Wahyudi 2012:41).

Dari pernyataan di atas dapat di pahami bahwa guru dalam menjalani tugasnya untuk menghasilkan kinerja yang maksimal didampingi oleh pemimpin yang berfungsi sebagai supervisor, dimana kepala sekolah memberikan bimbingan bagi guru yang belum 
dapat memahami tugas, mendengarkan keluhan guru dalam proses pengajaran atau membina guru membuat perencanaan pengajaran sampai mekalukan evaluasi kepada siswa.

Berkaitan dengan guru kerjuran maka dalam Salinan Permendikbud No.34 tahun 2018 Tentang Standar Nasional Pendidikan Sekolah Menengah Kejuruan dan Madrasah Aliyah Kejuruan di sebutkan "Guru kejuruan adalah guru pengampu mata pelajaran muatan kejuruan". Dengan demikian maka guru kejuruan merupakan tenaga pendidik yang kompeten mengajar mata pelajaran sesuai kejuruan ada di sekolah. Kinerja guru kejuruan menjadi sangat penting dilakukan karena tujuan dilakukannya penilaan kinerja (unjuk kerja) adalah untuk memberikan feedback kepada pegawai dalam upaya memperbaiki tampilan kerja, dan upaya meningkatkan produktifitas organisasi dengan berbagai kebijasanaan terhadap pegawai seperti untuk tujuan promosi, kenaikan gaji, pendidikan dan latihan (Daryanto, 2013:92). Jadi Penilaian kinerja berdampak positif bagi guru .

\section{METHODS}

Penelitian ini dilaksanakan dengan menggunakan pendekatan Deskriptif Kualitatif dan metode kasus. Teknik pengumpulan data yang di gunakan dalam penelitian ini adalah dengan mengunakan proses Triangulasi. Penetapan pengambilan sumber data dari SMK Teratai Putih Global 1 dan SMK Bisnis dan Teknologi di Kota Bekasi berdasarkan purposive sampling artinya penunjukan dilakukan sesuai dengan tujuan penelitian dengan kriteria yang ditentukan pula dan teknik pengambilan sample yaitu teknik Purposive sampling. Tetapi dalam kenyatannya dapat juga lebih meluas dengan denggunakan Snowball sampling. Adapaun proses tersebut di lakukan dengan cara observasi, wawancara, dokumentasi. Tahapan yang dapat memudahkan peneliti untuk mendapatkanya diantaranya, 1) Melalui perencanaan pembuatan pedoman wawancara,dokumentasi dan observasi; 2) Pelaksanaan ke lokasi; 3)Pelaksanaan pengamatan. Kemudian peneliti memilih informan sebagai objek adalah stakeholder yang ada di sekolah diantaranya Pengawas Sekolah, Kepala Sekolah, Guru, Tenaga Kependidikan, Siswa, Orang tua. Selanjutnya langkah langkah dalam analisis data Miles dan Huberman menyatakan "Model analisis data berlangsung atau mengalir (flow model analysis)", "Menurutnya ada empat aktivitas yang dilakukan melalui pendekatan ini yaitu : pengumpulan data, reduksi data, display data, Verivikasi/menarik kesimpulan" (Mukhtar 2013:135).

\section{RESULTS \& DISCUSSION}

\section{Results}

Dalam penelitian ini telah dilakukan pengumpulan data melalui observasi lapangan, dokumentasi pendukung dan hasil wawancara dengan para informan yang kompeten untuk mrndapatkan temuan temuan yang sesuai dengan pertanyaan penelitian berkaitan supervisi akademik kepala sekolah yang diteliti dari sudut fungsi manajemen seperti perencanaan, pengorganisasian, pelaksanaan, evaluasi, masalah dan solusi dalam meningkatkan kinerja guru kejuruan di Sekolah Menengah Kejuruan (SMK) di kota Bekasi.

Perencanaan supervisi akademik kepala sekolah dimotori oleh kepala sekolah adalah mengadakan pertemuan pada awal tahun pelajaran dengan mengundang unsur 
pimpinan, yayasan, pengawasan Sekolah Menengah Kejuruan, dewan guru, karyawan dan perwakilan orang tua dalam rangka sosialisasi kegiatan sekolah dan supervisi. Kemudian proses perencanaan supervisi akademik ditindaklajuti oleh tim supervisi yang dibentuk oleh kepala sekolah. Tim Supervisi ini dari tiap sekolah bervariasi adanya yang terdiri kepala sekolah, wakil Kurikulum dan guru senior serta Yayasan bahkan juga ada yang melibatkan Kepala Kompetensi yang ada di sekolah tersebut. Penugasan itu ini secara phisik terdokumentasi dalam surat Keputusan pengangkatan dan program Supervisi Kepala sekolah

Proses perencanaan yang dibuat diantaranya jadwal supervisi untuk masing masing supervisor, komponen yang harus disiapkan guru dalam supervisi seperti silabus, program semester, program tahunan, alokasi waktu, rencana program pebelajaran. Dalam persiapan juga tim supervisi membuat format rencana pembelajaran pembelajaran, format penilaian pebelajaran guru dan siswa, serts rekapitulasi hasil supervisi akademik. Selanjutnya proses pengorganisasian supervisi akademik yang dilakukan oleh sekolah sudah terlihat pembagian tugas yang berdasarkan personal yang dilibatkan menjadi tim supervisor. Seperti kepala sekolah, Wakil Kurikulum, Guru senior, Yayasan, dan Kepala komptensi maupun pengawas SMK di wilayah bersangkutan. Kemudian kepala sekolah juga menjelaskan tugas dan kewenangan setiap supervisor ketika melaksanakan supervisi akademik.

Pelaksanaan supervisi akademik yang dijalankan di lokasi penelitian menujukan di SMK kota Bekasi sepuervisor melaksanakan supervisi dengan menggunakan teknik kunjungan ke kelas, dan dalam pelaksanaannya mencakup 3 tahap yaitu :

1) Pra supersvisi kelas yaitu berkalitan dengan pemberkasan perangkat pembelajaran seperti RPP, indikator pencapaian komptensi, tujuan pembelajaran, kegiatan pembelajaran, media dan metode, serta penilaian.

2) Pelaksanaan pembelajaran yang terdiri dari kegiatan pendahuluan, kegiatan inti dan Penutup pemebelajaran

3) Penilaian pelakasanaan pembelajaran oleh guru dan siswa.

Teknik supervisi akademik yang lainya juga dilaksanakan dia antaranya percakapan pribadi, supervise klinis, diskusi kelompok, demonstrasi mengajar, kaji tindak dan action riset. Percakapan pribadi yang dilaksanakan oleh kepala sekolah dapat melalui 2 (dua) pendekatan formal dan informal, jika formal menggunakan undangan kepada guru yang terkategori mempunyai masalah, atau bisa juga atas dasar permintaan pribadi sang guru kepada kepala sekolah , jika informal dapat saat berbincang bincang diwaktu santai dan tidak terjadwal.

Dengan undangan maka seorang guru akan merasa dihargai oleh kepala sekolah dan privasi guru akan terjaga. Begitu juga dengan pembicaraan yang tidak formal menunjukan kedekatan kepala sekolah dengan guru dan seorang guru itupun tidak merasa menjadi takut atau teretekan dengan siatuasi kerja. Jika memang permasalahan guru muncul bersifat umum maka kepala sekolah akan lebih mengunakan diskusi kelompok untuk melaksanakan pemecahan masalah dan bimbingan. Proses diskusi kelompok ini memang juga paling banyak digunakan untuk memperbaiki kompetensi guru, seperti masalah yang dapat bersama sama diselesaikan, seperti menyusun materi ajar yang dibuat guru guru kejuruan maka diskusi kelompok ini akan sangat membantu dan guru akan merasa tidak sendiri dalam menyelesaikan kekurangannya.

Teknik supervisi lain dalam proses supervisi akademik ini adalah demontrasi mengajar, sebagai supervisor, seyogyanya kepala sekolah dapat juga memberikan contoh demonstrasi mengajar dalam mengatasi anak yang ribut atau hiperaktif di kelas. Dengan demonstrasi mengajar ini maka akan terlihat kepiawaian kepala sekolah di hadapan gurunya dan tentunnya akan membuat guru menjadi bangkit dan percaya diri karena 
pimpinan sekolah dianggap puntya kepedulian tinggi dengan guru gurunya. Di sisi lain dalam supervisi akademik, kepala sekolah dapat memberikan motivasi kepada guru guru kejuruan bahwa predikat yang guru yang disandangnya menuntut secara proses pembelajaran yang terus menerus mengikuti zaman atau perkembagan dunia usaha dan indusri. Inilah kesempatan kepala sekolah untuk memotivasi gurunya untuk selalu mencari tahu hal hal yang baru yang menunjang pembelajaran dengan memanfaat perpustakaan secara konvesional maupun perustakaan digital.

Dari pengamatan dan wawancara dalam penelitian ini, seharusnya penggunaan teknik supervisi pemanfaatan perustakaan ini lebih terasa manfaatnya jika penggunaannya merupakan kombinasi yang saling melengkapi. Kemudian disesuaikan dengan kebutuhan sang guru maupun kebutuan dari kurikulumya. Teknik supervisi inipun pada dasarnya sudah dijalankan di Sekolah Menengah Kejuruan kota Bekasi. Hal senada juga diberikan oleh guru matapelajaran kejuruan ketika dilakukan supervisi menyatakan menggunakan teknik kunjungan kelas dan mengundang guru memberikan masukan pada guru dan dapat terjadi pula sang guru biasayanya menanyakan kelemahan dirinya dan saya memberikan solusi. Temuan dari evaluasi supervisi akademik kepala sekolah dalam meningkattkan kinerja guru kejuruan mengacu pada perencanaan yang telah dibuat sebagai rambu rambu. Dan acuan pengambilan keputusan evaluasi oleh kepala sekolah diarahkan untuk pengambilan rencana tindak lanjut sekolah dalam peningkatan kinerja guru brikutnya.

Dari hasil evaluasi supervisi akademik kepala sekolah setelah dilaksanakan menunjukan adanya dinamika yang positif dari kineja guru kejuruan dari lokasi penelitian yaitu Sekolah Menengah Kejuruan di kota Bekasi. Proses monitoring dijalankan oleh wakil kepala sekolah setiap hari, memantau proses pembelajaran, piket, siswa tidak hadir, guru tidak hadir sampai dengan kebersihan kelas terpantau dengan laporan yang di buat setiap hari dengan mengunakan sosial media. Ini juga berdasarkan evaluasi porses pendidikan di Sekolah Menengah Kejuruan di kota Bekasi mengalami peningkatan kinerjanya dan setiap tindakan berbasis data yang ada, dan ini dapat dipertanggungjawabkan.

Secara laporan hasil supervisi Sekolah Menengah Kejuruan kota Bekasi mengambil instisari ya adalah:

1. Pada umumnya guru telah melaksanakan tugas dengan baik.

2. Hanya beberapa guru saja yang masih perlu bimbingan lebih lanjut dalam mempersiapkan dan melaksanakan kegiatan proses pembelajaran.

3. Banyak guru yang belum memiliki referensi yang cukup dalam memberikan materi pembelajaran

Dari laporan hasil supervisi maka tindak lanjut yang diambil adalah Guru masih memerlukan bimbingan diberikan pemahaman dan kesempatan untuk sitting in ( melihat contoh mengajar) pada kelas. Kemudian guru guru diberikan pelatihan rutin setiap tahun,bedah kurikulum untuk guru produktif per 3 bulan untuk meningkatkan kompetensinya,

Tindak lanjut supervisi akademik untuk guru kejuruan secara merata menunjukan perlu ditingkatkan dengan catatan khusus sebagai bahan pertimbangannya. Klasifikasi tindak lanjut dalam memberikan penguatan bagi guru bersifat perorangan dengan melaksanakan pembinaan secara internal oleh kepala sekolah, dengan kepala kompetensi atau guru senior jika berkaitan dengan matapelajaran kejuruan, jika bersifat umum maka diprogramkan pelatihan dengan fasilitas dan guru yang kompeten. Adapun jika tidak ada guru membutuhkan pelatihan dari luar dapat mengirim belajar atau memanggil guru untuk pelatihan di sekolah. 
Masalah yang muncul dari hasil supervisi akademik menujukan masih adanya kinerja guru kejuruan yang harus dilakukan perbaikan. Temuan masalah supervisi akademik kepala sekolah di Sekolah Menengah Kejuruan di kota Bekasi secara operasional secara kasus tentunya dimulai dari persiapan , pelaksanaan dan penilaian, pendampingan sampai dengan tindak lanjut. Pada saat persiapan guru dalam supervisi masih di temui perangkat pembelajaran yang kurang sesuai dengan kurikulum yang berlaku, guru kurang update ini dan ternyata masih adanya guru yang belum mengikuti pelatihan kurikulum 2013 revisi.

Dari hasil kepala sekolah saat kunjungan ke kelas mengamati guru mempunyai karakteristik yang berbeda, seperti perbedaan kemampuan kompetensinya yang kemudian juga supervisor harus melakukan pendampingan dengan cara berbeda pula. Masih ada guru yang bermasalah yaitu tidak konsistennya performa guru dalam proses belajar mengajar. Selain itu ada perubahan guru saat disupervisi, tapi ada juga yang lambat merespon, ada yang baik saat disupervisi tapi malas dalam keseharian, ini biasanya akan terlihat di hasil akhir kinerjanya dan kami jadikan catatan penting sebagai pembinaan. Bagi guru yang ingin maju biasanya termotivasi untuk tampil lebih baik.

Adanya temuan yang berarti dari hasil wawancara dengan kepala sekolah saya mengingatkan kepada supervisor adalah komunikasi harus dapat diterima oleh guru, kelemahan kita sebagai supervisor menyapaikannya terkadang dengan bahasa dan perilaku yang terkesan kurang diterima atau dipahami bahkan terkesan adanya penilaian antara atasan kepada bawahan bawahan dan terjadi pembiaran karena guru tersebut teman dekatnya. Permasalahan supervise akademik kepala sekolah juga muncul berkaitan dengan penggunaan media dan alat yang dipakai dalam pembelajaran yang dianggap masih baru bagi sang guru jadi penyesuaiannya lambat sehingga proses penyampaian kepada siswapun belum optimal.

Dari masalah yang ada maka Sekolah Menengah Kejuruan melakukan upaya upaya dalam meningkatkan kinerja guru kejuruan. Dalam rangka menindaklanjuti penguatan bagi kinerja guru kejuruan, telah dijawab oleh kepala sekolah bahwa supervisi akademik merupakan salah satu kunci keberhasilan dari program peningkatan kinerja guru kejuruan serta peserta didik, sehingga Sekolah Menengah Kejuruan di kota Bekasi konsisten melaksanakan supervisi akademik secara berkesinambungan dengan upaya upaya perbaikan dari segi fasilitas, diklat untuk guru dan tenaga kependidikan, termasuk dari program supervisi akademik itu sendiri.

Selanjutnya upaya upaya yang dilakukan kepala sekolah dalam hal ini memberdayakan tim supervisi akademik kepala sekolah yang terdiri dari wakil kepala sekolah bidang kurikulum, kepala kompetensi keahlian yang ada. Setelah supervisi kemudian memberikan rekomendasi ,seperti mengundang atau memberikan kesempatan pada induvidu guru untuk berkonsultasi secara pribadi, membuat pertemuan-pertemuan bagi guru yang sudah di kelompokan misalnya guru kejuruan, serta mendatangkan nara sumber. Di satu sisi juga proses monitoring yang diakukan oleh wakil kepala sekolah bidang kurikulum mengalami peningkatan pada proses pendidikan di Sekolah Menengah Kejuruan seperti memantau kegiatan belajar di kelas setiap hari, guru piket, guru tidak masuk dan kebeesihan kelas, siswa tidak ada hadir selau update tiap hari dan cepat mengambil tindakan berdasarkan data dan hasilnya dapat dipertanggung jawabkan

Selain itu tim supervisor terus memantau dan mendapingi guru guru kejuruan dalam memanfaatkan fasilitas yang digunakan secara maksimal.Kemudian setelah itu kembali kepala sekolah mengevaluasi. Terus secara berkesinambungan program supervisi akademik kepala sekolah menjadi program tetap yang mengikuti perubahan kondisi mengikuti visi, misi dan tujuan pendidikan sekolah dengan perkembangan pasar dunia usaha maupun industri. 


\section{Discussion}

Dalam penelitian ini perencanaan dilaksanakanan oleh Sekolah menengah yang diawali dengan mengundang semua komponen yang ada di sekolah mulai kepala sekolah, dewan guru, tenaga kendidikan, yayasan dan termasuk pengawas pembina SMK kota Bekasi, Agenda pertemuan ini merupakan sosialisasi yang berkaitan perencanaan program akademik. Di saat inilah seorang harus mampu untuk berkomunikasi dengan baik kepada guru

Mempertegas langkah yang diperlukan oleh supervisor Kepala sekolah melakukan pengkondisian dengan guru dan membahas rencana pembelajaran serta membuat instrument obeservasi kejuruan agar proses tahap awal perencanaan supervisi akademik dapat berjalan (Mulyasa, 2017:250-251). Hal ini tentu sejalan dengan hasil penelitian yang menyatakan kegiatan supervisi menaruh perhatian utama pada sosok guru, kemampuan supervisor membantu guru guru tercermin dalam memberikan bantuan kepada guru (Setiawati: 2018,7). Dalam menjalankan supervisi kepala sekolah juga dapat meminta bantuan pada guru senior atau wakilnya yang dianggap kompeten (Mulyasa, 2017:252)

Dalam supervisi akademik kepala sekolah dengan perorganisasian yang tepat mulai dari perekrutan tim supervisor, pembagian tugas, tanggung jawab dan kewenangannya sebelum bertugas. Kegiatan ini proses pengorganisasian merupakan aktivitas menyusun dan membentuk hubungan -hubungan kerja anatara orang-orang sehingga terwujud suatu kesatuan usaha dalam mencapai tujuan-tujuan yang telah ditetapkan (Purwanto:2014,16). Selain itu juga secara rutin menyamakan persepsi diantara supervisor yang dipimpin oleh kepala sekolah. Pemahaman tugas dari setiap indikator oleh tim supervisor diarahkan oleh kepala sekolah pada saat observasi kunjungan kelas terdiri dari a. tahap persiapan; $b$. Kegiatan pendahuluan; c. Kegiatan inti; d. Kegiatan penutup.

Tahap pelaksanaan supervisi akademik kepala sekolah selama ini berjalan secara umum Sekolah Menengah Kejuruan Kota Bekasi menjalani cara observasi kunjungan kelas kemudian diikuti proses pembimbingan dengan cara percakapan pribadi, demontrasi mengajar, supervisi klinis sesuai dengan kebutuhan dan evaluasi supervisor.Dalam melakukan observasi kunjungan kelas ,seorang supervisor mecermati tahap pra supervisi, yaitu supervisor melihat dan mencermati semua pernagkat pembelajaran yang di buat oleh seorang guru. Perangkat pembelajaran itu seperti kalender pendidikan, program semester, program tahunan, silabus matapelajaran, rencana program pembelajaran, modul, dan daftar hadir peserta didik.

Sejalan dengan hal di atas, pelaksanaan supervisi akademik kepala sekolah tentunya harus memilih teknik supervisi yang tepat sehingga akan dapat memotret kegiatan guru secara maksimal dan terlihat keunggulan dan hambatan yang dirasakan dalam proses pembelajaran. Supervisor di dalam kelas mulai dari masuk kelas sudah harus dapat mencermati suasana kelas, dan dapat mengetahui kemampuan guru dalam menguasai kelas. Dari hasil observasi dapat dikatakan guru mengusai kelas dengan cara memberikan salam, menayakan perserta didik yang tidak hadir sampai dengan mengatur posisi duduk peserta didik yang bermasalah saat belajar.

Catatan yang terjadi pada saat penagamtan guru lebih semangat mengajar dan peserta didik lebih kondusif dalam belajar, disamping itu juga masih adanya guru yang mengajar kurang sesuai materi dengan RPP nya, kurang tercapainya target pembelajaran saat itu, Jadi sangat penting rekaman berupa catatan dari seorang supervisor saat obseravsi karena ini merupakan proses identifikasi untuk dilanjutkan dalam evaluasi seorang guru sehingga akan lebih cepat dan akurat mengambil tindak lanjut. Walaupun 
demikian supervisor harus tetap memegang prinsip prinsip pelaksanaan supervisi seperti diantaranya "sitematis, objektif, realistic, antisipatif, kontruktif, kreatif, kooperatif dan kekeluargaan". Jelas lah dalam memberikan catatan dan penilaian tidak boleh terjadi "hallo effect" yang mengakibatkan hasil yang bias (Wahyudi: 2012,48-49).

Jadi teknik supervisi menurut pakar seperti teknik bersifat induvidu yang dilaksanakan adalah kunjungan obseravasi ke kelas dan percakapan pribadi. Teknik induvidul ini sangat lazim digunakan oleh kepala sekolah dikarenakan hasilnya dapat menjangkau aspek yang menjadi penilaian dari supervisor, seperti perilaku guru mengajar, kondisi peserta didik di kelas, media/metode yang digunakan sampai dengan guru melakukan pre/post tes serta bagaimana guru dapat membangun kelas menjadi aktif dalam pembelajaran. Perjalanan pembelajaran di dalam kelas dalam kegiatan inti seperti penggunaan metode dan media menjadi catatan tersendiri, kelemahan terlihat pada guru senior/sepuh yang lambat menyesuaikan penggunaan media belajar yang sebenarnya di butuhkan memenuhi kompetensi yang seharusnya diterima oleh peserta didik, ini menjadi catatan tersendiri. Selanjutnya kegiatan penutup secara umum guru sudah melaksanakan proses menutup pembelajaran dengan mengadakan tanya jawab sekitar materi dan diakhiri dengan salam.

Pelaksanaan supervisi juga dapat dilaksanakan dengan "Teknik yang lain juga banyak dilakukan kepala sekolah adalah pertemuan secara iduvidual " (Karsiyem,2015:208), teknik ini cukup membuat guru merasakan proses pembimbingan didalam guru menghadapi kesulitan dalam menjalani tugasnya sebagai guru, di samping itu guru merasa di hargai oleh kepala sekolah karena jika guru mengalami kekuranag tidak di ketahui oleh guru lain cukup kepala sekolah sebagai piminan sekolah. Evaluasi dalam supervisi akademik kepala sekolah di SMK di kota Bekasi sangat penting dilakukan untuk mengetahui kemajuan yang di dapat sehingga proses mencapai tujuan pembelajaran tercapai, hasilnya adalah adanya perubahan yang positf dari kinerja guru, dapat secara cepat mengatahui kesulitan yang dihadapi guru di kelas atau kondisi pribadinya sebagai guru, begitu pula hal yang berkaitan dengan peserta didik, bahkan penunjang pembelajaran seperti media belajar, sumber belajar. Dalam kontek ini kepala sekolah sebagai supervisor dan timnya dapat menjalankan proses evaluasi dengan mengacu pada perencanaan dan hasil pengamatan, monitoring dan penilaian dilapangan. Proses monitoring yang diajalan di dua sekolah juga dilaksanakan setiap saat secara fleksibel dari supervisor. Inipun didukung pernyataan yang menyebutkan dalam evaluasi supervisi akademik juga harus mempehatikan aspek pembinaan, pemantauan dan penilaian (Mulyadi: 2018,84-85).

Tahapan yang dilaksanakan oleh kepala sekolah adalah mengadakan pertemuan untuk melaksanakan evaluasi, semua tim yang terkait di undang. Tim supervisor yang terdiri dari wakil bidang kurikulum, guru senior, kepala komptensi keahlian, perwakilan yayasan dapat memberikan hasil pengamatan dan penilaian terhadap guru yang menjadi tanggung jawabnya saat di supervisi. Adapun pedoman yang digunakan oleh supervisor sesuai dengan intstrumen yang dibuat di sekolah masing masing yang intinya sama, kalaupun ada perbedaan, ini disebabkan oleh kondisi dan target yang beerbeda dari masing masing sekolah tersebut. Untuk mengambil keputusan dalam evaluasi tentuanya ada yang perlu diperhatikan seperti yang dinyatakan oleh Maunah (2017:276) meliputi :a) Keterbacaan dan keterlaksanaan program supervisi; b) Keterbacaan dan kemantapan instrument; c) Hasil supervise; d) Kendala yang dihadapi dan upaya pemecahannya.

Temuan program supervisi akademik secara inti untuk meningkatkan kemampuan guru dalam pembelajaran sudah dijalankan oleh sekolah sesuai kondisi sekolah, sehingga dapat dilihat dalam program supervisi akademik adanya variasi variasi target dan instrument. Ada yang menjadi konsentrasi peneliti adalah masalah akurasi catatan yang terdeskripsi dengan baik per guru belum terlihat dan belum terdokumentasi dengan baik 
sehingga di kahawatirkan hal ini akan menyulitkan pihak kepala sekolah dalam mengevaluasi serta mengambil tindak lanjut yang tepat sasaran bagi guru yang berada di sekolahnya.

Selanjutnya dalam pelaksanaaan pada saat observasi ke kelas masih ada guru yang masih belum menguasai kompetensi pedagogik, seperti penguasaan kelas , membaca karakter peserta didik dan masih nervous saat ada supervisor berada di kelas, masalah lain yang muncul adanya guru yang mempunyai perform yang baik pada saat dilakukan supervisi tapi pada saat sehari hari tidak menunjukan hal yang sama. Adanya persepsi di guru bahwa proses supervisi akademik itu hanya pada saat kunjungan di kelas sehingga setelah itu kemabali kehabit semula seperti mengajar dengan semaunya sendiri tidak berorientasi pada target kompetensi dasar yang diminta kurikulum, hal ini juga terlihat dalam dokumen Rencana Program Pembelajaran (RPP) berkaitan dengan evaluasi dalam pembuatan soal yang tidak berorientasi pada kompetensi yang di minta, ini tentunya berdampak pada lemahnya hasil belajar peserta didik begitu pula pada kinerja guru.Ada yang menjadi konsentrasi peneliti adalah masalah akurasi catatan yang terdeskripsi dengan baik per guru belum terlihat dan belum terdokumentasi dengan baik sehingga di kahawatirkan hal ini akan menyulitkan pihak kepala sekolah dalam mengevaluasi serta mengambil tindak lanjut yang tepat sasaran bagi guru yang berada di sekolahnya.

Sekolah Menegah Kejuruan ke depan akan terus menjadi sentral pendidikan yang dapat menghasilkan produk lulusan yang mempunyai skill yang dibutuhkan oleh dunia usaha dan industri. Pemerintah pun saat ini terus banyak memberikan bantuan bantuan yang diiformasikan melalui WEB kemendikbud, ini merupakan perhatian yang perlu direspon oleh sekolah dan guru kejuruan, disamping itu juga sudah makin banyaknya perusahaan perusahaan membuka diri melalui Corporate Social Resposibility (CSR) bekerja sama dengan sekolah untuk menjadi support system dari pendidikan di SMK.

Dari peluang dan kesempatan yang ada, maka dalam rangka meningkatkan kinerja guru kejuruan perlu ada tindak lanjut sebagai penguatan dengan :

1. Program supervisi akademik kepala sekolah harus selalu ditingkatkan secara mutu nya, dengan terdokumentasi deskripsi hasil dari catatan-catatan supervisi akademik kepala sekolah.Dan dalam teknik supervisi akademik dapat juga dilakukan melalui kunjungan ke dalam laboratoriun atau bengkel pada saat pelaksanaan pembelajaran praktek.

2. Tindak lanjut supervisi akademik kepala sekolah dengan pola pembentukan tim supervisi dalam pendampingan sangat membantu dalam meningkatkan kompetensi guru kejuruan.

3. Memberikan banyak kesempatan pada guru dalam meningkatakan kompetensinya seperti diklat dan diskusi kelompok maupun program program pelatihan secara induvidu maupun kelompok.

4. Terus mencari peluang untuk bekerja sama dengan dunia usaha dan industry dalam rangka meningkatkan mutu pembelajaran dan lulusan

5. Mengembangkan potensi peserta didik bidang ekstra kurikuler sebagai ajang kreatifitas dan inovasi serta komunikasi dalam rangka menunjang kegiatan belajar.

\section{CONCLUSION}

Perencanaan supervisi akademik kepala Sekolah Menengah Kejuruan kota Bekasi disusun oleh kepala sekolah, wakil kepala sekolah, perwakilan yayasan dan pengawas pembina SMK Kota Bekasi, kepala kompetensi keahlian dan guru serta tenaga kependidikan yang disepakati pada saat rapat lengkap Sekolah. Pada saat inilah Kepala sekolah memaparkan maksud, tujuan, target sesuai dengan kondisi sekolah masing 
masing. Perencanaan ini terprogram untuk satu tahun pelajaran yang dilaksanakan pada setiap semester dan dijadikan pedoman dalam rangka efektititas dan efisiensi pelaksanaan supervisi sehingga kepala sekolah dapat memantau dan mengecek kesiapan perjalanan tim supervisi akademik guru kejuruan.

Pengorganisasian merupakan bagian yang dapat membantu kepala Sekolah Menengah Kejuruan kota Bekasi menjalankan supervisi akademik dengan adanya pendelegasian, pembagian tugas, penjadwalan, batas waktu pelakasnaan, kewenangan, pelaporan sampai dengan pengambilan keputusan dalam evaluasi dan tindak lanjut. Dalam penggorganisasian pembagian tugas tim supervisor cenderung melihat kesesuaian latar belakang pendidikan dan mata pelajaran yang diampu. Adanya pendelegasian tugas walaupun tidak semua bisa pas pembagiannnya. Untuk supervisi di guru kejuruan dapat terlaksana sesuai pembagian tugasnya dikarenakan ada tim supervisi dari guru kejuruan masing masing.

Pada saat pelaksanaan supervisi akademik kepala Sekolah Menengah Kejuruan kota Bekasi dalam meningkatkan kinerja guru kejuruan, lebih berorientasi pada persiapan , pelaksanaan pembelajaran di dalam kelas dengan teknik observasi kunjungan ke kelas, dan penilaian. Dalam prosesnya tugas supervisor melaksanakan tiga hal diantaranya pembinaan, pemantauan dan penilaian. Proses Persiapan, guru sudah menyerahkan semua perangkat pembelajaran, guru sudah mengetahui jadwal observasi berdasarkan informasi dari supervisor dan saling menyepakati. Seluruh guru mengumpulkan perangkat pembelajaran, walaupun masih ada perbaikan perbaikan dalam menyusun peranggkat pembelajaran bersifat kasusitik di setiap guru. Kemudian pada saat observasi dengan teknik kunjungan ke kelas pun masih ada temuan yang menunjukan ketidak sesuaian jadwal, tetapi semua guru dapat di supervisi. Pada saat pelaksanaan yang bersifat kasusitik seperti kurang mampunya guru dalam penguasaan kelas, kurang dapatnya memanfatkan media, sumber belajar, dan kurang kreatif dan inovatif dalam pembelajaran,pada saat pengamatan yang dilaksanakan pada inti penilaian berdasarkan instrumen terkatagori baik. Instrumen supervisi akademik di masing masing sekolah mempunyai karakteristik masing masing dan ini merupakan sebuah pengkondisian yang dilakukan oleh tiap sekolah.

Proses evaluasi dari pelaksanaan supervisi akademik di Sekolah Menengah Kejuruan kota Bekasi dilaksanakan dengan pengumpulan data yang di dapat melalui perencanaan, pelaksanaan saat kunjungan ke dalam kelas, maupun monitoring yang bersifat tampak maupun hidden monitoring yang dilakukan oleh supervisor terhadap kegiatan guru dengan cara masuk kelas saat pembelajaran kosong, ataupun di luar kelas kepada siswa maupun dengan teman sejawat. Hasil evaluasi di dapat dari hasil rekomendasi seluruh tim supservisor yang dikumpulkan dalam rapat dan kepala sekolah mengambil keputusan terhadap hasil supervisi guru kejuruan, kemudian mengambil tindak lanjut terhadap guru kejuruan yang secara keseluruhan, Dokumentasi penilaian menjadi tindak lanjut dari supervisi akademik ke guru.

Masalah yang ada dalam supesrvisi akademik kepala Sekolah Menengah Kejuruan kota Bekasi masih memiliki beberapa kelemahan diantaranya bahwa:

a. Pada saat perencanaan kehadiran undangan dalam sosialisasi telah diajalankan semua hadir sehingga informsi tidak sampai secara menyeluruh. Persiapan guru yang kurang matang dalam sehingga ketika diperiksa masih terjadi kesalahan kesalahan. Format Rencana Program pembelajaran (RPP) setiap guru masih ada yang berbeda dalam satu sekolah dan adanya pembuatan evaluasi belajar dalam tes tertulis yang kurang sesuai dengan kompetensi dasarnya. Perangkat pembelajaran guru secara umum tertib mengumpulkan seluruhnya.

b. Pada saat penjadwalan yang masih terkadang berubah dikarenakan dari pihak supervisor maupun guru tersebut. 
c. Pada saat pelaksanaan supervisi secara kesuruhan guru menjalani proses ini dengan beberapa yang menjadi masalah yaitu adanya guru yang mempunyai performa baik saat di supervisi tapi pada saat keseharian menunjukan performa yang kurang, adanya guru yang kurang kreatif/inovatif dalam mengajar seperti penggunaan metoda dan media pembelajaran seperti sumber belajar, internet dan guru kurang terbiasa mencatata kekeurangan dan keunggulannya dalam RPPnya untuk perubahan ke depan. Adanya hambatan-hambatan atau perlunyan sinkronisasi dikarenakan perkembangan ilmu penegetahuan dan teknologi serta permintaan pasar dunia usaha dan industry maka penguatan kinerja guru kejuruan secara kontinyu dilakukan untuk mengatasi kekurangan atau melaksanakan pengayaan terhadap kemampunan guru.

Langkah langkah solusi yang dilakukan oleh Sekolah Menengah Kejuruan kota Bekasi dalam rangka meningkatkan kinerja guru harus terlihat nyata sehingga sekolah pun akan dapat hasil yang dapat dijadikan target dan tujuan dari supervisi akademik berikutnya. Arah dari peningkatan mutu kinerja ini tentu dari hasil supervisi akademik ini adalah pada penguasaan kompetensi kompetensi guru kejuruan. Memberikan kesadaran dan motivasi yang tinggi kepada guru dalam menjalankan tugas mulia melaksanakan pembelajaran kepada peserta didik di lingkungan pendidikan. Supervisi akademik kepala sekolah merupakan salah satu cara dalam melakukan peinilaian kinerja yang dapat dilaksanakan secara rutin di sekolah. Hasil supervisi akademik kepala sekolah merupakan keputusan penting dalam rangka tindak lanjut pembinaan, pengembangan dan meningkatkan kesejahteraan dari guru kejuruan.

\section{Saran}

Dari hasil penelitian dan simpulan maka dapat direkomendasikan beberapa hal sebagai berikut:

1. Rekomendasi untuk Kepala Sekolah

Kepala sekolah sebagai pemimpin di sekolah dapat terus memberikan kesempatan yang besar dalam pengembangan kompetensi-kompetensi guru mengingat perubahan ilmu dan teknologi yang cepat dikuti dengan pasar tenaga kerja di dunia usaha dan industri.Kebijakan yang selalu memberikan skala prioritas pemenuhan kebutuhan fasilitas yang berguna bagi guru kejuruan khususnya. Membangun kerjasama dengan dunia usaha dan industry, begitu juga dengan pemerintah dalam ranga mecari peluang bantuan yang berguna bagi penngembangan pemebelajaran.

2. Rekomendasi untuk Guru

Guru harus terus menerus mengembangkan kemampuan kompetensinya untuk dapat memberikan pembelajaran yang terbaik bagi peserta didiknya. Guru harus dapat menyadari bahwa dirinya dibutuhkan oleh peserta didik yang siap menimba ilmu dari dan tidak sekedar itu, guru mempunyai tanggung jawab moral secara pribadi dan soial pada agama dan negaranya dalam rangka meyiapkan generasi penerus.

3. Rekomendasi untuk Penelitian selanjutya

Penelitian ini merupakan salah satu langkah dalam meningkatkan kinerja guru kejuruan melalui supervisi akademik kepala sekolah, dan tentunya masih banyak lagi yang belum terjangkau, sehingga diperlukan penelitian penelitian berikutnya yang lebih tajam dan mendalam untuk menjadi bahan masukan dan wawasan sekolah dalam memajukan pendidikan di Negara tercinta, Negara Kesatuan Republik Indonesia. 


\section{REFERENCES}

Asmani, Jamal Ma'mur. (2012). Tip Efektif Supervisi Pendidikan Sekolah. Jogjakarta: Diva Press.

Daryanto. (2013). Konsep Dasar Manajemen Pendidikan di Sekolah. Yogyakarta: Gava Media.

Fiyanto, Ary. (2014). Manajemen Umum, Jakarta: Mitra Abadi.

Karsiyem, M. N. W. (2015). Pelaksanaan Supervisi Akdemik dalam Peninkatan kinerja Guru Sekolah Dasar Gugus III Sentolo Kulon Progo. Jurnal Akuntabilitas Manajemen Pendidikan. Vol.3, No.2, September 2015, p-ISSN:2337-7895,eISSN:2461-0550.

Kintamani, Ida. (2016). Analisis Sumber Daya Manusia Pendidikan Dasar dan Menengah Tahun 2015/2016, Kemendikbud, Pusat Data dan Statistik Pendidikan dan Kebudayaan

Leniwati, Yasir A. (2017). Implemteasi Supervisi Akademik Kepala Sekolah Untuk Meningkatkan Kinerja Guru. Jurnal Manajemen, Kepemimpinan, dan Supervisi Pendidikan (JMKSP). Volume 2, No. 1, Januari-Juni 2017.p-ISSN:2548-7094, eISSN:2614-8021.

Maunah, Binti. (2017). Supervisi Pendidikan Islam (Teori dan Praktek). Yoygakarta: Kalimedia.

Mukhtar. (2013). Orientai Baru Supervisi Pendidikan. Jakarta: Referensi ( Gaung Persada Press Group).

Mulyadi. (2018). Supervisi Akademik (Konsep, Teori, Model Perencanaan, dan Implikasinya). Malang: Madani Kelompok Intrans Publishing.

Mulyasa, E. (2013). Uji kompetensi dan Penilaian Kinerja Guru. Bandung: Remaja Rosdakarya.

. (2017). Manajemen dan Kepemimpinan Kepala Sekolah. Jakarta: Bumi Aksara.

(2020). Continuous Quality- Instructional Improvement through Implementation of an Internal Quality Assurance System. Systematic Review Pharmacy Journal. Vol 11, Issue 3, 2020. http://www.sysrevpharm.org/?mno=96341.

Permendikbud Nomor 34 tahun 2018. Tentang Standar Nasional Pendidikakan Sekolah Menengah Kejuruan/Madrasah Aliyah Kejuruan.

Purwanto, Ngalim. (2014). Administrasi dan Supervisi Pendidikan. Bandung: PT.Remadja Rodakarya.

Rostini, D. (2016). Implikasi Kinerja Kepala Sekolah dalam Manajemen Berbasis Sekolah di Tingkat Kabupaten. Jurnal Bimbingan dan Konseling Ar-Rahman. Volume 2, No.1, e-ISSN: 2477-6300.

Setiawati, Nur Amega., Tjipto Djuhartono, Hardian Mursito, (2018). Persepsi Guru tentang Supervisi Kepala Sekolah dalam Meningkatkan Kinerja guru. Jurnal Research and development Journal of Education.Volume 4 No.2, April 2018, ISSN:2406-9744.

Suhardan, Dadang, dkk. (2009). Manajemen Pendidikan. Bandung: Alfabeta.

Susanto, Hary. (2012). Faktor-Faktor yang Mempengaruhi Kinerja Guru, Jurnal Pendidikan Vokasi. Universitas Negeri Yogyakarta, Vol 2, Nomor 2, Juni 2012,pISSN: 2088-2866,e-ISSN: 2476-9041.

Syukri. (2015). Pelaksanaan Supervisi oleh Kepala Sekolah untuk Meningkatkan Kinerja Guru Sekolah Dasar pada Gugus I UPTD Dewnatara Aceh Utara. Jurnal Administrasi Pendidikan Pasca sarjana, Universitas Syiah Kuala, Volume 3, No. 2, Mei 2015, ISSN 2302-0156. 
Thoha, Miftah. (2007). Perilaku Organisasi Konsep Dasar dan Aplikasinya. Jakarta: Raja Grafindo Persada.

Wahyudi, Imam. (2012). Pengembangan Pendidikan (Strategi Inovatif dan Kreatif Dalam Mengelola Pendidikan Secara Komprhensif). Jakarta: PT. Prestasi Pustakaraya.

Yunus, S. (2017). Mengkritisi Kompetensi Guru. Detik News, Jumat, 24 November 2017. https://www.bing.com/search?q=Syarifudin+Yunus+dalam+detik.com $\% 282017 \% 2$ 9+\&form=EDGSPH\&mkt=idid\&httpsmsn $=1 \&$ msnews $=1 \&$ plvar=0 \& refig $=14 \mathrm{~b} 817$ 815442485ebf8d4fde3e7138ec \&PC $=$ LCTS $\& \mathrm{sp}=1 \& \mathrm{qs}=$ HS \&sk $=$ PRES1\&sc $=80 \& \mathrm{c}$ vid=14b817815442485ebf8d4fde3e7138ec\&cc=US\&setlang=en-US. 